\title{
The Effect of R\&D Expenditures on Earnings Management: A Research on Bist-All Shares
}

\author{
Yasar Bayraktar1 ${ }^{\oplus}$, Asiye Tutuncu2 $\odot$
}

\begin{abstract}
R\&D expenditures are important in increasing the level of information and technological development. Efficiency in production, cost reduction and competitive advantage are achieved with the added value created by successful R\&D activities. However, in the process of accounting and reporting the R\&D expenditures, some manipulative applications can be implemented by the business management for achieving personal or corporate targets. The purpose of this research is to reveal the effect of R\&D expenditures on earnings management. In this context, from 2007 to 2018,65 companies that made R\&D expenditures included in BIST-All Shares Index were examined. The earnings management effect calculated on the Modified Jones Model, taking into account the current period, one-year and two-year time lag of R\&D expenditures was tested with panel data analysis. As a result of the research, it was determined that R\&D expenditures negatively affect earnings management in the current period and positively in lagged periods. In addition, while size and leverage have negative effects on earnings management in the current period, one-year and two-year time lag, no statistically significant relationship was found in terms of return on assets.
\end{abstract}

Keywords

R\&D Expenditures, Earnings Management, Panel Data Analysis

\section{Introduction}

Research and Development (R\&D) activities are the basis of scientific and technological developments. The inventions and innovations that arise as a result of these activities are commercialized and benefits can be provided to the relevant stakeholders. However, R\&D activities are generally seen by stakeholders as investments involving high levels of uncertainty and information asymmetry. Therefore, it can be stated that current and prospective investors do not have exact information on whether these investments can provide output that can create added value. This situation paves the way for managers to use earnings management practices during the recognition and reporting of R\&D expenditures (Aboody \& Lev, 2000; Cristin, 2014).

\footnotetext{
1 Corresponding author: Yasar Bayraktar (PhD.), Karadeniz Technical University, Faculty of Economics and Administrative Sciences, Department of Business, Trabzon, Turkey. E-mail: ysr_bayraktar@hotmail.com ORCID: 0000-0002-6974-5292

2 Asiye Tutuncu (Asst. Prof.), Kastamonu University, Faculty of Economics and Administrative Sciences, Department of Banking and Finance, Kastamonu, Turkey. E-mail: ttncasiye@gmail.com ORCID: 0000-0001-9473-9401

To cite this article: Bayraktar, Y., \& Tutuncu, A. (2020). The Effect Of R\&D Expenditures on Earnings Management: A Research on Bist-All Shares. Istanbul Business Research, 49(2), 301-315. http://doi.org/10.26650/ibr.2020.49.0044
} 
Earnings management is expressed as the accounting manipulations that managers perform to make financial statements and reports presented to information users look different than they appear in order to achieve personal interests (Schipper, 1989; Mulford \& Comiskey, 2002). Managers can use earnings management practices in order to avoid earnings decreases and losses, achieve targeted profitability, increase the company's market value, create a strong financial structure image among stakeholders, meet expectations, eliminate the threat of displacement, and take advantage of tax benefits. (Burgstahler \& Dichev, 1997; Dechow \& Skinner, 2000; Shah, Butt \& Tariq, 2011; Dinh, Kang \& Schultze, 2016).

As a matter of fact, within the framework of earnings management practices managers can adopt the most appropriate approach of capitalization or expensing in the accounting treatment of R\&D expenditures in minimizing capital cost (Burgstahler \& Dichev, 1997), achieving earnings targets (Perry \& Grinaker, 1994; Mande, File \& Kwak, 2000; Roychowdhury, 2006), eliminating the restrictive obligations of debt contracts, smoothing income (Tucker \& Zarowin, 2006; Guidara \& Boujelbene, 2015), obtain managerial bonuses, reduce target dividend pressures and ease the company's tax burden (Mande et al., 2000). The selection of the appropriate approach can prepare the ground for the perception that earnings can be manipulated in the presence of stakeholders (Dinh et al., 2016).

On the other hand, the success or failure of the R\&D activities is important for the sustainability of the company and it can affect the interests of the stakeholders, including both shareholders and managers. In addition, this situation can be considered as a criterion in the evaluation of executive performance (Grabińska \& Grabiński, 2017). It is stated in the literature that the effect of R\&D investments on company profitability can be seen as delayed on average for two years (Lome, Heggeseth \& Moen, 2016), but this delay may change in the sectoral context (Pakes \& Schankerman, 1984). These delays include the time from the start of an R\&D project to the commercialization of the output at the end of the project (Pakes \& Schankerman, 1984). Considering the $R \& D$ intensity, the successful completion of the projects is important in terms of manager reputation. Within this context, it is also stated that earnings can be managed in order to reveal the success of the manager or hide the failure situation (Grabińska \& Grabiński, 2017).

R\&D intensity is expressed as an indicator of scientific and technological development and superiority. It is an important indicator of R\&D expenditures on micro and macroeconomic basis. The magnitude of the R\&D intensity on macroeconomic basis is calculated by proportioning R\&D expenditures to gross domestic product (Hughes, 1988). In this context, Turkey's R\&D intensity has been calculated as $1.03 \%$ as of 2018 and this rate is increasing over the years. In 2018, R\&D spending magnitude of $29 \%$ is observed compared to the previous year $(0.96 \%)$. In terms of the overall average of OECD countries, the R\&D intensity for 2018 is approximately $2.40 \%$ (OECD, 2020). Turkey is below the average of developed 
countries and OECD average in terms of R\&D intensity. The magnitude of the R\&D intensity on microeconomic basis is calculated by proportioning R\&D expenditures to Total Assets (Oswald, 2008; Persson \& Fuentes, 2011; Grabińska \& Grabiński, 2017) or R\&D expenditures to Net Sales (Osma \& Young, 2009; Guidara \& Boujelbene, 2015; Lome et al., 2016; Grabińska \& Grabiński, 2017). Considering the R\&D intensity, private sector has a higher share in R\&D expenditures compared to other sectors. In addition, while the private sector R\&D expenditure was $37 \%$ in 2006, it reached $60.4 \%$ in 2018 (TUBITAK, 2019).

Earnings management is an intentional interference in the financial reporting process to reach specific goals. Although earnings management practices can lead to benefits for managers in the short run, it may cause serious problems in the long run. Since it directly affects the economic and operational efficiency which threatens the firms' sustainability. Besides, it causes a decrease in the accounting information quality. For these reasons, the importance of R\&D expenditures effect on earnings management should be taken into consideration. Therefore, it is essential to shed light on R\&D effect in terms of earnings management. In this context, the purpose of this research is to reveal the effect of $R \& D$ expenditures on earnings management. For this purpose, the earnings management effect calculated on the Modified Jones Model, taking into account the current period, one-year and two-year time lag of R\&D expenditures was tested with panel data analysis. Through this study, the researchers can examine whether R\&D expenditures have an effect on earnings management. Thus, a wide range of information users such as shareholders, investors, market participants, financial analysts can make better rational strategic decisions. In the following sections of this study, the literature, methodology, findings and conclusion will be included.

\section{Literature}

In the literature, on the one hand it is stated that capitalization may cause earnings management and therefore should be expensed directly. On the other hand, it is emphasized that $R \& D$ expenditures are investments related to intangible assets that can create added value and therefore should be capitalized (Healy, Myers \& Howe, 2002). In the adoption of the capitalization approach in accounting for R\&D expenditures; leverage, size, earnings variability (Daley \& Vigeland, 1983; Landry \& Callimaci, 2003; Oswald, 2008), return on assets (Markarian, Pozza \& Prencipe, 2008; Persson \& Fuentes, 2011), benchmarking (Dinh et al., 2016) can be effective. It is also stated that the capitalization approach contributes to the presentation of information with a high level of value relevance for current and prospective investors (Aboody \& Lev, 1998; Healy et al., 2002; Dinh \& Schultze, 2011; Kumari \& Mishra, 2019; Khidmat, Wang \& Awan, 2019). On the other hand, the R\&D expensing can enable companies to reduce their tax burdens (Hirschey \& Weygandt, 1985; Percy, 2000; Mande et al., 2000). Adopting the capitalization approach contributes to the increase in the 
company's asset size; it can also expand its financing opportunities. However, the failure of R\&D projects may cause the management to lose reputation. In addition, the expensing of $R \& D$ causes lower profits to be reported in the relevant period. Thus, it can create a prejudice against innovative investments and prepare the ground for not allocating sufficient resources. Therefore, it is emphasized that both approaches can affect the company value positively/ negatively (Oswald \& Zarowin, 2007; Seybert, 2010). In the light of these explanations, a number of international studies listed chronologically about the effect of R\&D expenditures on earnings management are shown below.

Mande et al. (2000) examined whether Japanese managers adjust R\&D expenditures to smooth income in terms of R\&D expensers and capitalizers. They found that less profitable, smaller, more leveraged and R\&D intensive firms intend to capitalize R\&D expenditures for earnings management purposes. They also stated that Japanese managers adjust their R\&D budget for income smoothing and manage firms' earnings.

Landry and Callimaci (2003) investigated the effects of management incentives and cross-listing status on $R \& D$ accounting treatment for Canadian R\&D intensive firms. By using logistic regression model, they examined the determinants of R\&D capitalization/expensing. They found that capitalization probability increases for firms that are more mature, leveraged and have higher operation cash flows. Besides, for larger and more profitable firms intend not to capitalize R\&D. They suggested that the decision about to expense or capitalize R\&D can be used as an earnings management tool for smoothing income and meeting debt covenants.

Markarian et al. (2008) examined whether Italian listed firms' decision to capitalize R\&D expenditures are affected by earnings management. They aimed to test the decision to expense (when flexibility is available) or to capitalize R\&D expenditures affected by income smoothing and debt contracting motives. Their results show that firms which have higher ROA (return on assets) are more likely to expense while firms which have lower ROA are more likely to capitalize. This result is consistent with income smoothing purposes. However R\&D capitalization is not used to decrease the risk of violating debt covenants. They also stated that R\&D capitalization is an effective signal for potential investors who utilize financial statements in terms of value relevance.

Persson and Fuentes (2011) examined whether Swedish firms use R\&D accounting treatment (to capitalize or to expense) as a tool for smoothing income. They aimed to determine the relationship between $R \& D$ accounting treatment classification and earnings management incentives. By using multiple regression analysis, they found that high level of ROA variation gives managers more incentives to apply earnings management. They also stated that $R \& D$ accounting treatment can be used for income smoothing. 
Guidara and Boujelbene (2014) examined whether discretionary R\&D accounting treatment can be affected by earnings management purposes. As a result of the research carried out in 410 French firms it was determined that R\&D capitalization isn't used for income smoothing. They also found that earnings management, which is realized by strategically cutting $\mathrm{R} \& \mathrm{D}$ expenditures, is carried out in order to increase financial performance.

Zicke (2014) examined the incentives behind R\&D capitalization. As a result of the research carried out in 506 German firms it was determined that the R\&D capitalization is used as an indicator of financial success for earnings management purposes. It has been stated that practices such as loss avoidance, earnings decreasing and income smoothing are effective motives in $\mathrm{R} \& \mathrm{D}$ capitalization.

Guidara and Boujelbene (2015) examined whether earning targets affect R\&D cut after IFRS adoption. As a result of the research carried out in 800 French firms it was determined that earnings management, which was realized by manipulating R\&D expenditures, was carried out in order to smooth income. They also stated that R\&D cut is managerial strategic decision to increase performance for earnings management purposes.

Dinh et al. (2016) examined whether R\&D capitalization can be applied by managers to signal private information about future economic benefit and can be served as earnings management. They found that R\&D capitalization was made for benchmark beating and earnings management. Besides, it has been stated that earnings management will decrease the market value.

Grabinska and Grabinski (2017) examined the impact of R\&D expenditures on earnings management. They aimed to analyze the relationship between R\&D intensity and earnings management. It was determined that managerial discretion regarding $R \& D$ expenditures is intended to earning management. Besides R\&D spending is an important determinant of earnings management after a two-year time lag.

Dumas (2017) examined whether reducing R\&D spending and R\&D capitalization techniques are used to meet earnings thresholds by French firms. It was determined that R\&D capitalization and the R\&D cut were made by managers in order to meet target earnings. It was also stated that these two approaches are substitutes for each other and can be used as a tool for earnings management.

Considering the previous literature, it became clear that in most of the studies, the effect of the accounting treatment of R\&D expenditures on earnings management was examined. Besides, there is no study in Turkey directly addressing the effect of R\&D expenditures on earnings management. With this aspect, the study is expected to contribute to the literature. 


\section{Data Set and Methodology}

In this study, the effect of R\&D expenditures on earnings management is examined. From 2008 to 2018, 65 companies that made R\&D expenditures included in BIST-All Shares Index were discussed. In calculating some variables, data related to the previous period is needed. For this reason, the scope of analysis has been expanded and data has been organized since 2007. In this context, it can be stated that the used data set covers 2007-2018 periods and consists of 715 observations.

The data to be analyzed within the scope of the study were obtained from the companies' year-end financial statements (statement of financial position, comprehensive income statement) and/or annual reports. It is seen that a significant portion of the companies analyzed within the scope of BIST-All do not have "Development Costs" in the statement of financial position. In addition, it is seen that there is no information on R\&D expenditures in the footnotes. Contrary to this situation, it was determined that these expenditures were reported in the comprehensive income statement. Therefore, it can be stated that companies within the scope of the analysis adopt the approach of R\&D expensing. However, in this study, the effect of these expenditures on earnings management was analyzed by considering $R \& D$ intensity, size, leverage and return on assets (ROA) rather than accounting approaches.

In the literature, there are many models developed by Healy (1985), DeAnGelo (1986) and Jones (1991) in calculating earnings management. However, Jones (1991), unlike other models, takes into account the total accruals that have a large place in manipulating profits rather than discretionary accruals. The Jones Model, which is frequently used in the calculation of earnings management, has been modified and developed over time. In this context, by developing Industry Model - Dechow \& Sloan (1991), Modified Jones Model-Dechow, Sloan \& Sweeney (1995), Larcker-Richardson Model-Larcker \& Richardson (2004), Performance Matched Discretionary Accrual Measurement Model - Kothari, Leone \& Wasley (2005) contributed to the literature in the calculation of earnings management.

In this study, earnings management was calculated using the Modified Jones Model developed by Dechow et al. (1995). There are several reasons for the preference of this model due to the assumptions of other models. The Industry Model (Dechow et al., 1995), based on the assumption that the companies operating in the same sector, the discretionary determinants of accrual are similar, were not used due to the firms operating in different sectors. On the other hand, in the Larcker-Richardson Model, the profit obtained from the operating activities is added to the Modified Jones Model (Larcker \& Richardson, 2004). Currently, this variable is also included in the total accruals calculated by the equation (1). Finally, the return on assets $(R O A)$ variable included in the Performance Matched Discretionary Accrual Measurement Model is added to the model as a control variable in examining the effect of $R \& D$ expenditures on earnings management. The fact that the same variable 
is included in the calculation of earnings management and model leads to some specification errors. For this reason, this model was not preferred to have healthier results in the study.

In the Jones Model, earnings management is represented by discretionary accruals. In this model, discretionary accruals consist of the difference between total accruals and non-discretionary accruals. In this context, the error terms obtained from the equation (2) solved by the OLS (Ordinary Least Squares) method are used in determining the discretionary accruals.

$$
\begin{gathered}
T A_{i, t}=\frac{N I E I_{i, t}-C F O_{i, t}}{A_{i, t-1}}(1) \\
T A_{i, t}=\alpha_{1 i}\left[\frac{1}{A_{i, t-1}}\right]+\alpha_{2 i}\left[\frac{\Delta R E V_{i, t}}{A_{i, t-1}}\right]+\alpha_{2 i}\left[\frac{P P E_{i, t}}{A_{i, t-1}}\right]+u_{i, t}(2)
\end{gathered}
$$

The results obtained from the Modified Jones Model are more effective than the results obtained from the Jones Model (Dechow et al., 1995; Kothari et al., 2005). In this framework, taking into account the receivables, the Modified Jones Model, which is shown with the equation (3), was used and the discretionary accruals were calculated. By solving the equation with OLS, error terms were determined by the coefficients.

$$
T A_{i, t}=\delta_{1 i}\left[\frac{1}{A_{i, t-1}}\right]+\delta_{2 i}\left[\frac{\Delta R E V_{i, t}-\Delta R E C_{i, t}}{A_{i, t-1}}\right]+\delta_{2 i}\left[\frac{P P E_{i, t}}{A_{i, t-1}}\right]+v_{i, t}(3)
$$

In equations (2) and (3) $A_{i, t-1}$, is lagged value of total assets; $\Delta$ is the change in variables; $u_{i, t}$ and $v_{i, t}$ are error terms. In addition, other variables in the equations (1), (2) and (3) used in the study are shown in Table 1.

It is stated in the literature that the effects of $R \& D$ expenditures on earnings management appear in the future (Grabińska \& Grabiński, 2017). In this framework, the equation used by Grabińska \& Grabiński (2017) was taken as a basis in order to demonstrate the impact of R\&D expenditures on earnings management. In terms of R\&D intensity, two different R\&D variables were obtained by dividing the R\&D by total assets (R\&D1) and net sales (R\&D2). At the same time, size, leverage and return on assets as control variables are included in the equations in order to determine the relationship. Regression models created within this framework are as follows:

\section{Model 1:}

$$
E M_{i, t}=\alpha_{0}+\alpha_{1} R \& D 1_{i, t-j}+\alpha_{2} S I Z E_{i, t}+\alpha_{3} R O A_{i, t}+\alpha_{4} L E V_{i, t}+\varepsilon_{i, t}
$$

\section{Model 2:}

$$
E M_{i, t}=\alpha_{0}+\alpha_{1} R \& D 2_{i, t-j}+\alpha_{2} S I Z E_{i, t}+\alpha_{3} R O A_{i, t}+\alpha_{4} L E V_{i, t}+\epsilon_{i, t}
$$


Table 1

Variables

\begin{tabular}{lll}
\hline Variables & Explanations & Calculation and References \\
\hline TA & Total Accruals & (Net Income Before Extraordinary Items - Cash Flows \\
A & Total Assets & $\begin{array}{l}\text { From Operations) / Lagged Total Assets } \\
\text { (Statement of Financial Position) }\end{array}$ \\
REV & Property, Plant and Equipments & (Statement of Financial Position) \\
REC & Net Sales & (Comprehensive Income Statement) \\
NIEI & Receivables & (Statement of Financial Position) \\
CFO & Net Income Before Extraordinary Items & (Comprehensive Income Statement) \\
SIZE & Operating Cash Flows & (Statement of Cash Flows) \\
& Firm Size & Logarithm of Total Assets (Landry \& Callimaci, 2003; \\
& & Guidara \& Boujelbene, 2015; Dinh et al., 2016; Grabińska \\
ROA & Return on Assets & \& Grabiński, 2017) \\
& & Net Profit/Total Assets (Landry \& Callimaci, 2003; \\
& & Markarian et al., 2008; Dinh et al., 2016; Grabińska \& \\
LEV & Financial Leverage & Grabiński, 2017) \\
& & Total Liabilities/Total Assets (Guidara \& Boujelbene, \\
R\&D1 & R\&D Intensity & 2015; Dinh et al., 2016; Grabińska \& Grabiński, 2017) \\
& & R\&D/Total Assets (Oswald, 2008; Persson \& Fuentes, \\
R\&D2 & R\&D Intensity & 2011; Grabińska \& Grabiński, 2017) \\
& & R\&D/Net Sales (Osma \& Young, 2009; Guidara \& Boujel- \\
& & bene, 2015; Lome et al., 2016; Grabińska \& Grabiński, 2017) \\
\hline
\end{tabular}

EM in the equation (4) and (5) represents the earnings management; $j=0,1,2$ lagged periods; $\varepsilon_{i, t}$ ve $\epsilon_{i, t}$ error terms. Earnings management was obtained by using the error terms of the total accrual equation (3) calculated by the OLS method. Panel data analyzes were carried out to reveal the current period, one-year and two-year lagged in Model 1 and Model 2, which were designed to measure the earnings management effect of R\&D. Hausman Test was used to determine which of the panel data analysis methods in terms of fixed and random effects is valid. Considering the unit properties, fixed effects model is used in order to obtain more consistent estimators.

\section{Findings}

The findings obtained as a result of the analyzes carried out within the scope of the study will be presented separately for the results of Hausman Test, followed by Fixed Effects Panel Data Analysis for R\&D1 and R\&D2 models. In addition, the effect of R\&D expenditures on earnings management will be summarized in terms of the current period, one-year and twoyear. In the light of these explanations, Hausman Test result related to Model 1 is shown in Table 2. 
Table 2

Model 1-Hausman Test Results

\begin{tabular}{|c|c|c|c|c|c|}
\hline \multirow{2}{*}{ Time Lag } & \multirow{2}{*}{ Variables } & \multicolumn{2}{|c|}{ Coefficients } & \multirow{2}{*}{ (b-B) } & \multirow{2}{*}{$\left.\begin{array}{c}\text { Diag } \\
\left(V_{-} \mathbf{b}-V_{-} B\right.\end{array}\right)$} \\
\hline & & FE (b) & RE (B) & & \\
\hline \multirow{4}{*}{ R\&D1 Model } & R\&D1 & -0.1277 & -0.1185 & -0.0091 & 0.0161 \\
\hline & SIZE & -0.1119 & -0.1081 & -0.0038 & 0.0013 \\
\hline & ROA & -0.0009 & -0.0008 & -0.0001 & 0.0007 \\
\hline & LEV & -0.0174 & -0.0151 & -0.0023 & 0.0001 \\
\hline \multirow{4}{*}{ R\&D1 (-1) Model } & R\&D1 (-1) & 0.0939 & 0.0357 & 0.0582 & 0.0166 \\
\hline & SIZE & -0.1097 & -0.1061 & -0.0036 & 0.0011 \\
\hline & $\mathrm{ROA}$ & -0.0017 & -0.0016 & -0.0007 & 0.0002 \\
\hline & LEV & -0.0189 & -0.0162 & -0.0028 & 0.0008 \\
\hline \multirow{4}{*}{ R\&D1 (-2) Model } & R\&D1 (-2) & 0.1354 & 0.0562 & 0.0792 & 0.0177 \\
\hline & SIZE & -0.1166 & -0.1115 & -0.0051 & 0.0013 \\
\hline & ROA & 0.0088 & 0.0022 & 0.0066 & 0.0017 \\
\hline & LEV & -0.0202 & -0.0173 & -0.0029 & 0.0099 \\
\hline Hausman Test Statistic & \multicolumn{5}{|c|}{$\begin{array}{l}\mathrm{R} \& D 1 \chi_{4}^{2}=15.70(0.003) \\
\mathrm{R} \& D 1(-1) \chi_{4}^{2}=29.07(0.000) \\
\operatorname{R} \& D 1(-2) \chi_{4}^{2}=42.25(0.000)\end{array}$} \\
\hline
\end{tabular}

As seen in Table 2, R\&D1 shows panel data analysis results including current period, R\&D1 (-1) one-year lag and R\&D (-2) two-year lag. According to the Hausman Test result, $\mathrm{H}_{0}$ hypothesis is rejected, which states that it will be more effective to analyze models that take into account all three time lags by using the random effects estimator. For this reason, the effects of R\&D1 variable on earnings management are examined by panel data analysis. In addition, robust estimators were used to eliminate diagnostic problems. The results of the fixed effects panel data analysis for Model 1, which includes the R\&D1 (R\&D/Total Assets) variable, are shown in Table 3.

As can be seen in Table 3, R\&D expenditures negatively affect earnings management at $\mathbf{5 \%}$ significance level in the current period; in terms of R\&D1 (-1) and R\&D1 (-2) models, it has a positive effect on the level of $\mathbf{1 \%}$ significance. Hausman Test results of Model 2 which includes the R\&D2 (R\&D/Net Sales) are shown in Table 4.

As in R\&D1 models, the $\mathrm{H}_{\mathrm{O}}$ hypothesis was rejected because the Hausman Test statistic was smaller than the $X^{2}$ test statistic in R\&D2 models. According to the Hausman Test; when all three time lags are taken into account, it can be stated that the results obtained with fixed effects will be more consistent. Therefore, R\&D2 model fixed effects are solved by panel data analysis. These fixed effects panel data analysis results obtained using robust estimators are shown in Table 5. 
Table 3

Model 1-Fixed Effects Panel Data Analysis Results

\begin{tabular}{llllll}
\hline Time Lag & Independent Variables & Coefficient & Standard Error & t-statistic & p-value \\
\hline R\&D1 Model & R\&D1 & -0.1277 & 0.0603 & -2.12 & 0.038 \\
& SIZE & -0.1119 & 0.0350 & -3.20 & 0.002 \\
& ROA & -0.0009 & 0.0016 & -0.57 & 0.568 \\
& LEV & -0.0174 & 0.0063 & -2.77 & 0.007 \\
& C & 0.0017 & 0.0052 & 0.33 & 0.739 \\
R\&D1 (-1) Model & R\&D1 (-1) & 0.0939 & 0.0222 & 4.22 & 0.000 \\
& SIZE & -0.1097 & 0.0301 & -3.64 & 0.001 \\
& ROA & -0.0017 & 0.0013 & -1.31 & 0.195 \\
& LEV & -0.0189 & 0.0067 & -2.86 & 0.006 \\
R\&D1 (-2) Model & R\&D1 (-2) Model & 0.0939 & 0.0047 & 0.06 & 0.951 \\
& SIZE & 0.1354 & 0.0239 & 5.89 & 0.000 \\
& ROA & -0.1166 & 0.0326 & -3.57 & 0.001 \\
& LEV & 0.0088 & 0.0066 & 1.33 & 0.188 \\
Diagnostic Tests & C & -0.0202 & 0.0075 & -2.70 & 0.009 \\
& & 0.0011 & 0.0057 & 0.20 & 0.843
\end{tabular}

Table 4

Model 2-Hausman Test Results

\begin{tabular}{|c|c|c|c|c|c|}
\hline \multirow[t]{2}{*}{ Time Lag } & \multirow[t]{2}{*}{ Variables } & \multicolumn{2}{|c|}{ Coefficients } & \multirow[t]{2}{*}{ (b-B) } & \multirow{2}{*}{$\begin{array}{c}\text { Diag } \\
\left(V_{-} \mathbf{b}-V_{-} B\right)\end{array}$} \\
\hline & & FE (b) & RE (B) & & \\
\hline \multirow[t]{4}{*}{ R\&D2 Model } & $\mathrm{R} \& \mathrm{D} 2$ & -0.0856 & -0.0674 & -0.0183 & 0.0202 \\
\hline & SIZE & -0.1056 & -0.1021 & -0.0035 & 0.0008 \\
\hline & ROA & -0.0016 & -0.0014 & -0.0002 & 0.0020 \\
\hline & LEV & -0.0182 & -0.0158 & -0.0024 & 0.0007 \\
\hline \multirow[t]{4}{*}{ R\&D2 (-1) Model } & $\mathrm{R} \& \mathrm{D} 2(-1)$ & -0.0137 & -0.0311 & 0.0174 & 0.0149 \\
\hline & SIZE & -0.1102 & -0.1065 & -0.0038 & 0.0010 \\
\hline & ROA & -0.0017 & -0.0016 & -0.0001 & 0.0002 \\
\hline & LEV & -0.0193 & -0.0166 & -0.0027 & 0.0008 \\
\hline \multirow[t]{4}{*}{ R\&D2 (-2) Model } & $\mathrm{R} \& \mathrm{D} 2(-2)$ & 0.0392 & -0.0057 & 0.0449 & 0.0166 \\
\hline & SIZE & -0.1173 & -0.1111 & -0.0062 & 0.0014 \\
\hline & ROA & 0.0076 & 0.0015 & 0.0061 & 0.0019 \\
\hline & LEV & -0.0208 & -0.0176 & -0.0031 & 0.0009 \\
\hline Hausman Test Statistic & \multicolumn{5}{|c|}{$\begin{array}{c}\mathrm{R} \& \mathrm{D} 2 \chi_{4}^{2}=15.73(0.003) \\
\mathrm{R} \& \mathrm{D} 2(-1) \chi_{4}^{2}=16.09(0.000) \\
\mathrm{R} \& \mathrm{D} 2(-2) \chi_{4}^{2}=30.00(0.000)\end{array}$} \\
\hline
\end{tabular}


Table 5

Model 2-Fixed Effects Panel Data Analysis Results

\begin{tabular}{lccccc}
\hline Time Lag & Independent Variables & Coefficient & Standard Error & t-statistic & p-value \\
\hline R\&D2 Model & R\&D2 & -0.0856 & 0.0259 & -3.20 & 0.002 \\
& SIZE & -0.1056 & 0.0289 & -3.65 & 0.001 \\
& ROA & -0.0016 & 0.0011 & -1.38 & 0.174 \\
& LEV & -0.0182 & 0.0062 & -2.93 & 0.005 \\
R\&D2 (-1) Model & C & 0.0018 & 0.0044 & 0.39 & 0.695 \\
& R\&D2 (-1) & -0.0137 & 0.0167 & -0.82 & 0.413 \\
& SIZE & -0.1102 & 0.0303 & -3.63 & 0.001 \\
& ROA & -0.0017 & 0.0013 & -1.35 & 0.181 \\
& LEV & -0.0193 & 0.0066 & -2.91 & 0.005 \\
R\&D2 (-2) Model & C & 0.0018 & 0.0047 & 0.38 & 0.704 \\
& R\&D2 $(-2)$ & 0.0392 & 0.0442 & 0.89 & 0.379 \\
& SIZE & -0.1173 & 0.0336 & -3.48 & 0.001 \\
& ROA & 0.0076 & 0.0066 & 1.15 & 0.238 \\
LEV & -0.0208 & 0.0075 & -2.77 & 0.007 \\
& C & 0.0024 & 0.0054 & 0.45 & 0.651
\end{tabular}

As can be seen in Table 5, R\&D expenditures only negatively affect earnings management at the $\mathbf{1 \%}$ significance level in the current period. In terms of other time lags, a statistically significant relationship could not be determined. However, size and leverage are the control variables shown in Table 3 and Table 5, where the results of fixed effects panel data analysis in terms of Model 1 and Model 2 are included; in three models including current period, oneyear and two-year lag, it was determined that they negatively affected earnings management at $1 \%$ significance level. On the other hand, it is determined that the variable of return on assets in these models is not effective on earnings management.

The effects of R\&D expenditures, which are determined by using the fixed effects panel data analysis in line with Model 1 and Model 2, which differ in the measurement of R\&D intensity, are summarized in Table 6.

Table 6

Effect of R\&D Expenditures on Earnings Management

\begin{tabular}{ccc}
\hline Time Lag & R\&D1 & R\&D2 \\
\hline 0 & $(-)^{*}$ & $(-)^{* * *}$ \\
1 & $(+)^{* * *}$ & \\
2 & $(+)^{* * *}$ & \\
\hline
\end{tabular}

Note: $* * *, *$ show statistical significance at $1 \%$ and $5 \%$, respectively.

As can be seen in Table 6, it was determined that R\&D expenditures, Model 1-R\&D (R\&D/Total Asset) and Model 2-R\&D2 (R\&D/Net Sales) negatively affect earnings management in terms of current period. Similarly, Mande et al. (2000), Guidara \& Boujelbene (2015) 
and Dinh et al. (2016) also revealed that R\&D intensity has a negative effect on earnings management. In terms of lagged periods, only the Model 1-R\&D1 variable was determined to positively affect earnings management. As a matter of fact, Aboody \& Lev (1998) and Percy (2000) state that R\&D intensity has a positive effect on earnings management.

On the other hand, considering firm size and leverage in terms of control variables in Model 1 and Model 2; it is seen that three models, including the current period, one-year and two-year lag, negatively affect earnings management at $1 \%$ significance level. Similarly, Daley \& Vigeland (1983), Aboody \& Lev (1998), Percy (2000), Landry \& Callimaci (2003), Wang \& D'Souza (2006), Persson \& Fuentes (2011), Guidara \& Boujelbene (2015), Dinh et al. (2016) and Grabińska \& Grabiński (2017), size; Mande et al. (2000), Markarian et al. (2008), Persson \& Fuentes (2011) and Grabińska \& Grabiński (2017) revealed that the leverage negatively affects earnings management. In terms of return on assets, considering the current period and time lags, Aboody \& Lev (1998), Landry \& Callimaci (2003), Markarian et al. (2008), Persson \& Fuentes (2011) and Dinh et al. (2016) contrary to their results, a statistically significant relationship could not be determined.

\section{Conclusion}

Since R\&D investments contain more uncertainty and are risky compared to other investments, it is important for all stakeholders that the expenditures made within this scope create economic added value to meet the expectation level. In this context, managers as a stakeholder can make financial statements look different than they appear with a number of earnings management practices in order not to lose reputation due to the failure of $R \& D$ projects. As a result of the study, it was determined that R\&D expenditures negatively affect earnings management in the current period, while it positively affects lagged periods. In terms of control variables, considering size and leverage; it was seen that the three models including the current period, one-year and two-year lag negatively affect earnings management at $1 \%$ significance level. In terms of return on assets (ROA) variable, a statistically significant relationship could not be determined. Thus, it can be stated that $R \& D$ expenditures are effective on earnings management.

In this context, increasing the quality of auditing, performing financial reporting regarding these activities in line with the principle of transparency, achieving the faithful representation and relevance in reporting, making internal control systems effective and improving corporate governance approach can be effective in reducing earnings management practices. Moreover, it is important to take measures for improving the competencies of auditing and accounting members who are responsible for detecting the financial information manipulation. So, it is necessary to raise awareness about the risks originating from earnings management practices and its adverse outcome on accounting information quality. On the other hand, The Capital Markets Board of Turkey should take measures to ensure that companies 
pay maximum attention to compliance with Corporate Governance Principles. In addition, the Capital Markets Board should ensure that matters relating to non-compliant principles are reasonably explained and measures taken against conflicts of interest that may arise due to non-compliance with the principles.

In the research, the data were drawn from the annual financial statements and reports. For this reason, the possibility of errors in hand-collected data can be expressed as a constraint. In addition, the number of observations is less compared to the researches in the international literature. However, this situation stems from the fact that R\&D activities are carried out by certain companies and can be explained by the fact that the faithful representation and fair presentation was not realized during the reporting period of the R\&D expenditures. In future research, the effect of accounting approaches of R\&D expenditures on earnings management can be evaluated. In addition, by making comparisons before and after TAS/TFRS, the effect of accounting standardization on earnings management can be measured.

Peer-review: Externally peer-reviewed.

Conflict of Interest: The authors have no conflict of interest to declare.

Grant Support: The author declared that this study has received no financial support.

\section{References}

Aboody, D. \& Lev, B. (1998). The value relevance of intangibles: The case of software capitalization. Journal of Accounting Research, 36, 161-191.

Aboody \& Lev, B. (2000). Information asymmetry, R\&D and insider gains. The Journal of Finance, 55(6), 2747-2766.

Burgstahler, D., \& Dichev, I. (1997). Earnings management to avoid earnings decreases and losses. Journal of Accounting and Economics, 24, 99-126.

Cristin, N. T. (2014). The accounting for intangible assets and impact of assets impairment. Ovidius University Annals, Series Economic Sciences, 14(1), 684-689.

Daley, L. A., \& Vigeland, R. L. (1983). The effects of debt covenants and political costs on the choice of accounting methods. Journal of Accounting and Economics, 5, 195-211.

DeAngelo, L. (1986). Accounting numbers as market valuation substitutes: A study of management buy outs of public stockholders. The Accounting Review 61(3), 400-420.

Dechow, P. M., \& Sloan, R. G. (1991). Executive incentives and the horizon problem: An empirical investigation. Journal of Accounting and Economics, 14(1), 51-89.

Dechow, P. M., Sloan, R. G., \& Sweeney, A. P. (1995). Detecting earnings management. The Accounting Review, 70(2), 193-225.

Dechow, P., \& Skinner, D. (2000). Earnings management: Reconciling the views of accounting academic, practitioners and regulators. Accounting Horizons, 14(2), 235-250.

Dinh, T., \& Schultze, W. (2011). Capitalizing research\&development and other information: The incremental information content of accruals vs. cash flows. Journal of Management Control, 22, 241-278. 
Dinh, T., Kang, H., \& Schultze, W. (2016). Capitalizing research\&development: Signaling or earning management?. European Accounting Review, 25(2), 373-401.

Dumas, G. (2017). Processual earnings management: A study of R\&D spending of french listed companies. Comptabilite-Controle-Audit, 23(2), 111-141.

Grabińska, B., \& Grabiński, K. (2017). The impact of R\&D expenditures on earnings management. Argumenta Oeconomica Cracoviensia, 17, 53-72.

Guidara, R., \& Boujelbene, Y. (2014). R\&D based earnings management and accounting performance. International Journal of Academic Research in Accounting, Finance and Management Sciences, 4(2), 81-93.

Guidara, R., \& Boujelbene, Y. (2015). R\&D expenditures and earnings targets: Evidence from France. Journal of Economics, Finance and Accounting, 2(2), 164-180.

Healy, P. M. (1985). The effect of bonus schemes on accounting decisions. Journal of Accounting and Economics 7(1-3), 85-107.

Healy, P. M., Myers, S. C., \& Howe, C. D. (2002). R\&D accounting and the tradeoff between relevance and objectivity. Journal of Accounting Research, 40(3),677-710.

Hirschey, M. \& Weygandt, J. (1985). Amortization policy for advertising and research and development expenditures. Journal of Accounting Research, 23(1), 326-335.

Hughes, K. (1988). The interpretation and measurement of R\&D intensity-A note. Research Policy, 17, $301-$ 307.

Jones, J. J. (1991). Earnings management during import relief investigations. Journal of Accounting Research, 29(2), 193-228.

Kothari, S. P., Leone, A. J., \& Wasley, C. A. (2005). Performance matched discretionary accrual measures. Journal of Accounting and Economics, 39, 163-197.

Kumari, P., \& Mishra, C. S. (2019). Value relevance of R\&D reporting in India: Significance of intangible intensity. Journal of Financial Reporting and Accounting, 17(3), 432-448.

Khidmat, B. W., Wang, M., \& Awan, S. (2019). The value relevance of R\&D and free cash flows in an efficient investment setup. Asian Journal of Accounting Research, 4(1), 95-111.

Landry, S., \& Callimaci, A. (2003). The effect of management incentives and cross-listing status on the accounting treatment of R\&D spending. Journal of International Accounting, Auditing\&Taxation, 12, 131-152.

Larcker, D. F., \& Richardson, S. A. (2004). Fees paid to audit firms, accrual choices and corporate governance. Journal of Accounting Research, 42(3), 625-658.

Lome, O., Heggeseth, A. G., \& Moen, Q. (2016). The effect of R\&D on performance: Do R\&D-intensive firms handle a financial crisis better?. Journal of High Technology Management Research, 27, 65-77.

Mande, V., File, R. G., \& Kwak, W. (2000). Income smoothing and discretionary expenditures of Japanese firms. Contemporary Accounting Research, 17(2), 263-302.

Markarian, G., Pozza, L., \& Prencipe, A. (2008). Capitalization of R\&D costs and earnings management: Evidence from Italian listed companies. The International Journal of Accounting, 43(3), 246-267.

Mulford, C., \& Comiskey, E. (2002). The financial numbers game, detecting creative accounting practices. John Wiley\&Sons. Inc., New York, USA.

OECD (2020). Main science and technology indicators. 2019(2). OECD Publishing, Paris-France.

Osma, B. G., \& Young, S. (2009). R\&D expenditure and earnings targets. European Accounting Review, 18(1), 7-32. 
Oswald, D. R. (2008). The determinants and value relevance of the choice of accounting for research and development expenditures in the United Kingdom. Journal of Business Finance \& Accounting, 35(1), 1-24.

Oswald, D. R., \& Zarowin, P. (2007). Capitalization of R\&D and informativeness of stock prices. European Accounting Review, 16(4), 703-726.

Pakes, A., \& Schankerman, M. (1984). The rate of obsolescence of patents, research gestation lags, and the private rate of return to research resources. In Z. Griliches (Ed.), R\&D, Patents, and Productivity. University of Chicago Press.

Perry, S., \& Grinaker, R. (1994). Earnings expectations and discretionary research and development spending. Accounting Horizons, 8(4), 43-51.

Percy, M. (2000). Financial reporting discretion and voluntary disclosure: Corporate research and development expenditure in Australia. Asia-Pacific Journal of Accounting \& Economics, 7(1), 1-31.

Persson, A., \& Fuentes, K. (2011). R\&D capitalization and the income smoothing hypothesis-A study of Swedish listed companies. Master Thesis in Accounting, Auditing and Analysis, 1-29.

Roychowdhury, S. (2006). Earnings management through real activities manipulation. Journal of Accounting and Economics, 42(3), 335-370.

Schipper, K. (1989). Earnings management. Accounting Horizon, 66(4), 91-102.

Seybert, N. (2010). R\&D capitalization and reputation-driven real earnings management. The Accounting Review, 85(2), 671-693.

Shah, S. Z. A., Butt, S., \& Tariq, Y. B. (2013). International financial reporting standards and the value relevance of R\&D expenditures: Pre and post IFRS analysis. International Review of Financial Analysis, 30, 158-169.

TUBITAK (2019). Gerçekleştirilen sektörler bazında ar-ge harcamaları. Erişim adresi: https://www.tubitak. gov.tr/sites/default/files/289/bty15_1.pdf

Tucker, J. W., \& Zarowin, P. A. (2006). Does income smoothing improve earnings informativeness. The Accounting Review, 81(1), 251-270.

Wang, S., \& D'Souza, J. (2006). Earning management: The effect of accounting flexibility on R\&D investment choices. Johnson School Research Paper Series, 33-06, 1-39.

Zicke, J. (2014). Capitalization of R\&D costs and implications for earnings management. Retrieved from https://ssrn.com/abstract=2198307 